Article

\title{
The role of water in photocatalytic dissociation of methanol on rutile $\mathrm{TiO}_{2}(110)-(1 \times 1)$
}

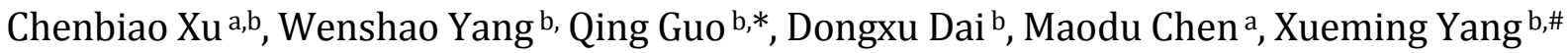 \\ a Department of Physics and Optoelectric Engineering, Dalian University of Technology, Dalian 116023, Liaoning, China \\ b State Key Laboratory of Molecular Reaction Dynamics, Dalian Institute of Chemical Physics, Chinese Academy of Sciences, Dalian 116023, Liaoning, \\ China
}

\section{A R T I C L E I N F}

Article history:

Received 23 November 2013

Accepted 13 December 2013

Published 20 March 2014

\section{Keywords:}

Methanol

Water

Rutile $\mathrm{TiO}_{2}(110)-(1 \times 1)$

Photocatalysis

Temperature-programmed desorption

Formaldehyde

\begin{abstract}
A B S T R A C T
We have performed a surface photocatalysis study of the molecularly adsorbed forms of methanol on a vacuum-annealed rutile $\mathrm{TiO}_{2}(110)-(1 \times 1)$ surface using temperature-programmed desorption both with and without coadsorbed water to investigate the effect of water and methanol on the photocatalytic dissociation of each other on rutile $\mathrm{TiO}_{2}(110)-(1 \times 1)$. Our experimental results show conclusively that methanol has no effect on photocatalytic water splitting with water covered rutile $\mathrm{TiO}_{2}(110)-(1 \times 1)$ surface. Further experimental results also show that water does not affect the process of photocatalytic methanol dissociation but does suppress photo-induced desorption of the formaldehyde product of methanol photocatalysis and can enhance the formation of the methyl formate product.
\end{abstract}

(C) 2014, Dalian Institute of Chemical Physics, Chinese Academy of Sciences. Published by Elsevier B.V. All rights reserved.

\section{Introduction}

Since Fujishima and Honda [1] demonstrated in 1972 that $\mathrm{TiO}_{2}$ can be used to photocatalytically split water in a photoelectric chemical cell, the application of this material as a catalyst/photocatalyst in water splitting as well as photodegradation of organic molecules has been extensively investigated [2-9]. It is now well known that while pure $\mathrm{TiO}_{2}$ is photocatalytically inactive for splitting water to produce hydrogen [10], adding methanol can dramatically enhance its photocatalytic activity for hydrogen production [11]. This effect has been attributed to the role of methanol as a hole scavenger or hole trapper allowing efficient separation of the electron-hole pair to help the separated electrons to catalyze the water splitting reaction.

$\mathrm{CH}_{3} \mathrm{OH}$ and $\mathrm{H}_{2} \mathrm{O}$ on rutile $\mathrm{TiO}_{2}(110)-(1 \times 1)$ have served as model systems for surface photocatalytic studies [12-22]. Dohnalek et al. [23] used scanning tunneling microscopy (STM) to show that $\mathrm{CH}_{3} \mathrm{OH}$ molecules are molecularly adsorbed on the $\mathrm{Ti}_{5 \mathrm{C}}$ sites and are dissociated only at bridge bonded oxygen (BBO) vacancy sites. These results are consistent with the temperature-programmed desorption (TPD) studies of Henderson and coworkers [13]. Recently, an excited electronic state on the $\mathrm{CH}_{3} \mathrm{OH} /$ rutile $\mathrm{TiO}_{2}(110)-(1 \times 1)$ surface was observed in a two photon photoemission (2PPE) study [24,25], and we attributed this surface state to a photocatalytically dis-

\footnotetext{
* Corresponding author. Tel: +86-411-84379337; Fax: +86-411-84675584; E-mail: guoqing@dicp.ac.cn

\# Corresponding author. Tel: +86-411-84695174; Fax: +86-411-84675584; E-mail: xmyang@dicp.ac.cn

This work was supported by the National Basic Research Program of China (973 Program, 2013CB834605) and the National Natural Science Foundation of China (20923002).

DOI: 10.1016/S1872-2067(14)60006-1 | http://www.sciencedirect.com/science/journal/18722067 | Chin. J. Catal., Vol. 35, No. 3, March 2014
} 
sociated state of $\mathrm{CH}_{3} \mathrm{OH}$ on the surface using combined time-dependent 2PPE (TD-2PPE) and STM [26].

In a very recent study, we have investigated the photocatalysis of $\mathrm{CH}_{3} \mathrm{OH}$ and $\mathrm{H}_{2} \mathrm{O}$ on rutile $\mathrm{TiO}_{2}(110)-(1 \times 1)$ using a newly developed universal photocatalysis apparatus in combination with theoretical calculations [27]. Our results indicate that photocatalytic dissociation of $\mathrm{CH}_{3} \mathrm{OH}$ of rutile $\mathrm{TiO}_{2}(110)-(1 \times 1)$ occurs on the Ti5c sites in a stepwise manner, in which the $\mathrm{O}-\mathrm{H}$ dissociation proceeds first and is then followed by $\mathrm{C}-\mathrm{H}$ dissociation. As a result, product formaldehyde $\left(\mathrm{CH}_{2} \mathrm{O}\right)$ is formed in the photocatalysis of $\mathrm{CH}_{3} \mathrm{OH}$. This picture can be readily explained by theoretically calculated ground state reaction pathways. However, under exactly the same experimental conditions, photocatalytic dissociation of $\mathrm{H}_{2} \mathrm{O}$ on rutile $\mathrm{TiO}_{2}(110)-(1$ $\times 1$ ) has not been detected. Shen and Henderson [21] recently attempted to investigate this issue and detected no photocatalytic dissociation of either $\mathrm{CH}_{3} \mathrm{OH}$ or $\mathrm{H}_{2} \mathrm{O}$ [23]. This is likely due to the weak light source used in their photocatalysis experiment. To understand whether $\mathrm{CH}_{3} \mathrm{OH}$ could aid $\mathrm{H}_{2} \mathrm{O}$ splitting or $\mathrm{H}_{2} \mathrm{O}$ could affect $\mathrm{CH}_{3} \mathrm{OH}$ dissociation, we have carried out a cautious experimental study on a mixed $\mathrm{CH}_{3} \mathrm{OH} / \mathrm{H}_{2} \mathrm{O}$ covered rutile $\mathrm{TiO}_{2}(110)-(1 \times 1)$ surface using the same photocatalysis apparatus as that reported in Ref. [27].

\section{Experimental}

The TPD apparatus has been previously described [27]. The base pressure of the sample chamber was $<6 \times 10^{-11}$ Torr. A quadrupole mass spectrometer (Extrel) was used to detect desorbed products. An extremely high vacuum of $1.5 \times 10^{-12}$ Torr in the electron-impact ionization region was achieved and maintained during experiments. The rutile $\mathrm{TiO}_{2}(110)-(1 \times 1)$ (Princeton Scientific) single crystal had dimensions of $10 \mathrm{~mm} \times$ $10 \mathrm{~mm} \times 1 \mathrm{~mm}$. The surface was cleaned by cycles of $\mathrm{Ar}^{+}$sputtering and resistive heating to $850 \mathrm{~K}$ in vacuum until any contamination was below the detection limit of AES and a well-ordered rutile $\mathrm{TiO}_{2}(110)-(1 \times 1)$ LEED pattern with a low background was observed. The rutile $\mathrm{TiO}_{2}(110)-(1 \times 1)$ surface contained 3\%-4\% O-vacancy defects as determined by $\mathrm{H}_{2} \mathrm{O}$ TPD. $\mathrm{CH}_{3} \mathrm{OH}$ (Aldrich, > 99.9\%) was further purified by several freeze-pump-thaw cycles before use and introduced into the sample chamber with a calibrated molecular beam doser. The surface temperature was maintained at $\sim 100 \mathrm{~K}$ during $\mathrm{CH}_{3} \mathrm{OH}$ dosing and subsequent UV irradiation.

The irradiating light came from a frequency doubled Ti:Sapphire femtosecond laser at $400 \mathrm{~nm}$ (coherent, repetition rate $1 \mathrm{kHz}$ ). The average intensity on the sample was about 7.2 $\times 10^{17}$ photons $\mathrm{cm}^{-2} \mathrm{~s}^{-1}(200 \mathrm{~mW})$. The $400 \mathrm{~nm}$ laser used for surface irradiation in this experiment had a beam diameter of 6 $\mathrm{mm}$ and an incident angle of $\sim 30^{\circ}$ with respect to the rutile $\mathrm{TiO}_{2}$ (110)-(1 $\left.\times 1\right)$ surface, which was mounted with an angle point at the top. Using $200 \mathrm{~mW}$ laser power, the $\mathrm{TiO}_{2}$ surface temperature was increased to $\sim 150 \mathrm{~K}$ from the base surface temperature of $\sim 100 \mathrm{~K}$. TPD measurements of the various surface products were then made to probe the photocatalytic products that stayed on the surface after photoirradiation, while time-of-flight measurements were used to probe gaseous species produced from the surface during laser irradiation.

\section{Results and discussion}

Figure 1 (a) shows the selected TPD spectra at a mass-to-charge ratio $(\mathrm{m} / \mathrm{z})$ of $31\left(\mathrm{CH}_{2} \mathrm{OH}^{+}\right)$after the clean rutile $\mathrm{TiO}_{2}(110)-(1 \times 1)$ surface was dosed with $0.3 \mathrm{ML}(1 \mathrm{ML}=5.2 \times$ $10^{14}$ molecules $\mathrm{cm}^{-2}$ ) of $\mathrm{CH}_{3} \mathrm{OH}$ and $0.2 \mathrm{ML}$ of $\mathrm{H}_{2} \mathrm{O}$, and was then irradiated by the $400 \mathrm{~nm}$ laser for different periods of time. The main peak around $310 \mathrm{~K}$ in the spectra is due to molecular $\mathrm{CH}_{3} \mathrm{OH}$ desorption from $\mathrm{Ti}_{5 \mathrm{C}}$ sites. From the TPD spectra it is obvious that $400 \mathrm{~nm}$ laser irradiation depleted the $\mathrm{CH}_{3} \mathrm{OH}$ TPD signal. The integrated TPD signals for this peak at different irradiation times are shown in Fig. 1 (b) and clearly indicate that the TPD signal decreased monotonically as laser irradiation time increased. This implies that the $\mathrm{CH}_{3} \mathrm{OH}$ molecules adsorbed on the $\mathrm{Ti}_{5 \mathrm{C}}$ sites were photocatalytically dissociated. After 60 min laser irradiation, about $20 \%$ of the $\mathrm{CH}_{3} \mathrm{OH}$ molecules on the surface were dissociated.

We also made similar measurements for $0.3 \mathrm{ML} \mathrm{CH}_{3} \mathrm{OH}$ only covered rutile $\mathrm{TiO}_{2}(110)-(1 \times 1)$ surface for comparison. The $\mathrm{CH}_{3} \mathrm{OH}$ TPD peak depletion as a function of laser irradiation
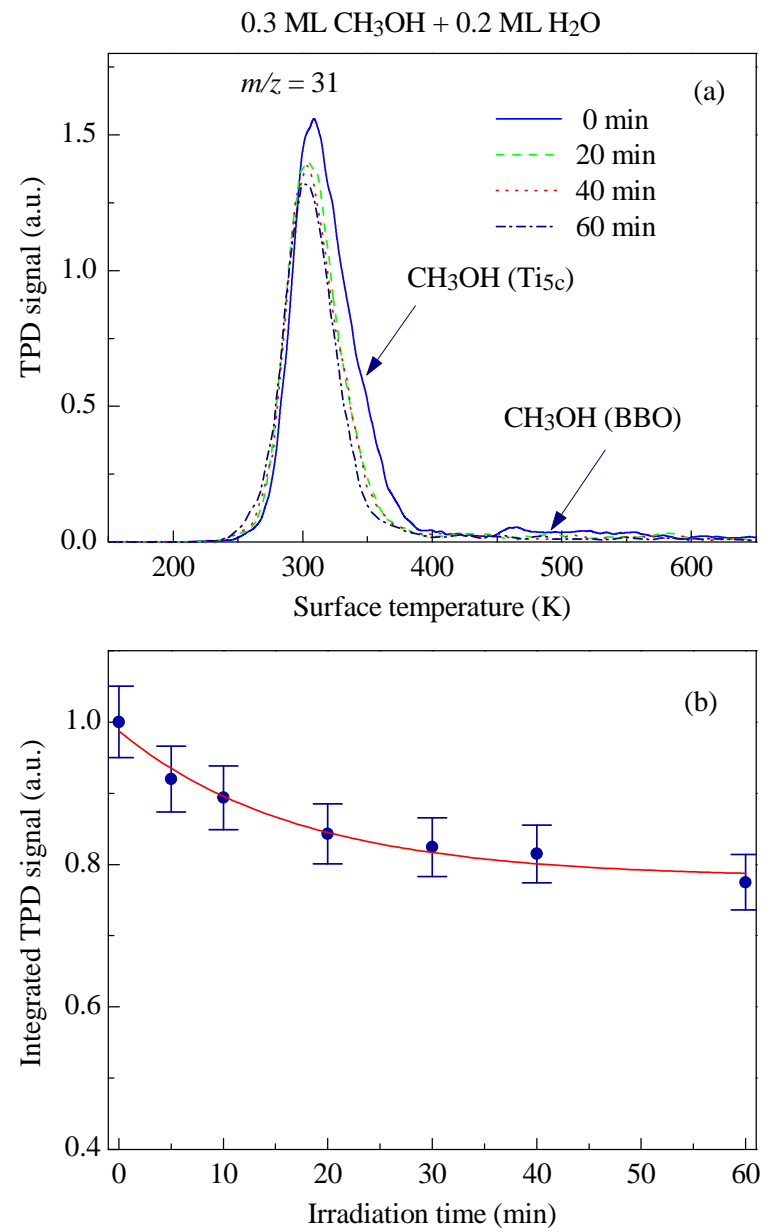

Fig. 1. (a) TPD spectra taken at $m / z=31$ at four different laser irradiation times; (b) Integrated signal of the TPD peak at $315 \mathrm{~K}$ at mass 31 after the $\mathrm{CH}_{3} \mathrm{OH} / \mathrm{H}_{2} \mathrm{O}$ covered rutile $\mathrm{TiO}_{2}(110)-(1 \times 1)$ surface was irradiated with $400 \mathrm{~nm}$ laser light for different periods of time. 

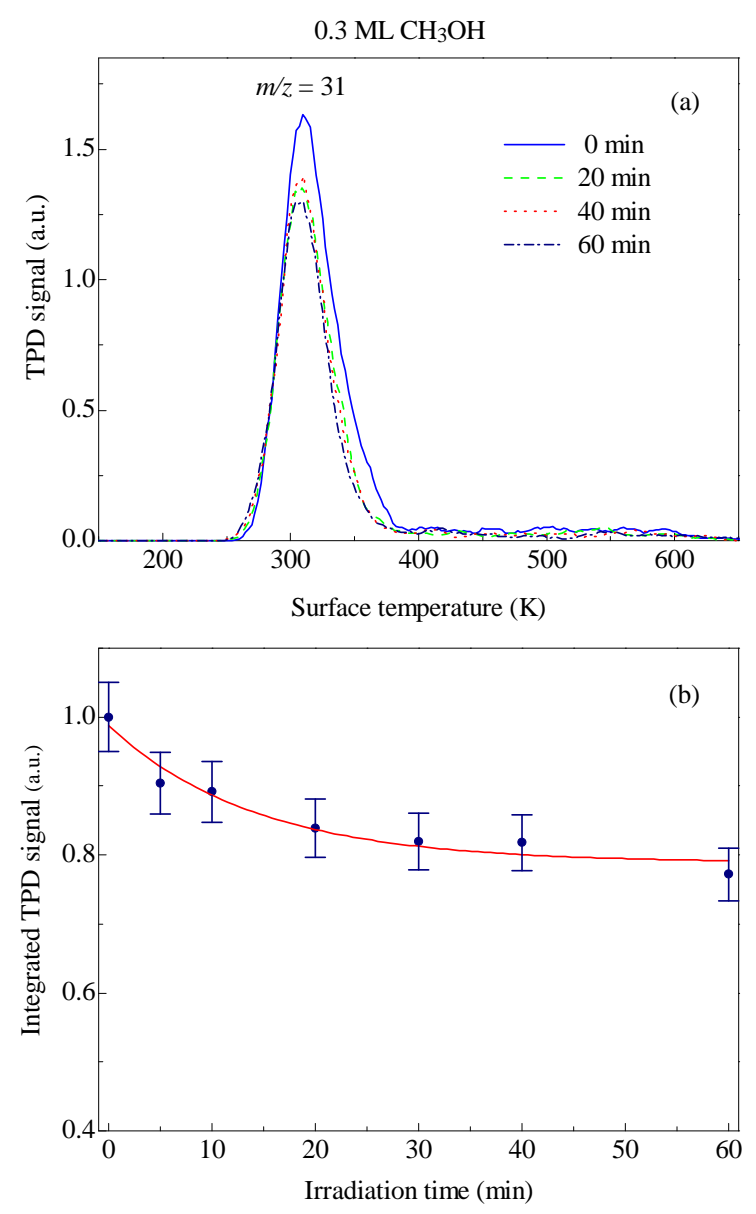

Fig. 2. (a) TPD spectra taken at $m / z=31\left(\mathrm{CH}_{2} \mathrm{OH}^{+}\right)$at four different laser irradiation times for the $0.3 \mathrm{ML} \mathrm{CH}_{3} \mathrm{OH}$ covered rutile $\mathrm{TiO}_{2}(110)$ $(1 \times 1)$ surface; (b) The integrated signal of the TPD peak at $315 \mathrm{~K}$ at mass 31 shown in (a) after the surface was irradiated with $400 \mathrm{~nm}$ laser light for different periods of time.

time (Fig. 2) on this surface was very similar to that for the 0.3 $\mathrm{ML} \mathrm{CH} 33 \mathrm{OH}+0.2 \mathrm{ML} \mathrm{H}_{2} \mathrm{O}$ covered rutile $\mathrm{TiO}_{2}(110)-(1 \times 1)$ surface. Furthermore, we also measured the $\mathrm{CH}_{3} \mathrm{OH}$ TPD peak depletion as a function of laser irradiation time for the $0.3 \mathrm{ML}$ $\mathrm{CH}_{3} \mathrm{OH}+0.4 \mathrm{ML} \mathrm{H}_{2} \mathrm{O}$ covered rutile $\mathrm{TiO}_{2}(110)-(1 \times 1)$ surface (Fig. 3). In fact, the results of $\mathrm{CH}_{3} \mathrm{OH}$ TPD peak depletion on these three surface samples are all similar (Fig. 4). This indicates that the presence of $\mathrm{H}_{2} \mathrm{O}$ on the rutile $\mathrm{TiO}_{2}(110)-(1 \times 1)$ surface does not affect $\mathrm{CH}_{3} \mathrm{OH}$ photocatalytic dissociation process in a significant way.

In addition, we also observed the $\mathrm{CH}_{2} \mathrm{O}$ product ( $270 \mathrm{~K}$ TPD peak) from the photocatalysis of $\mathrm{CH}_{3} \mathrm{OH}$ (Fig. 5 (a)) for the same surface, which is clearly produced via the stepwise photocatalytic dissociation of $\mathrm{CH}_{3} \mathrm{OH}$ on rutile $\mathrm{TiO}_{2}(110)-(1 \times 1)$ [27]:

$$
\begin{aligned}
\mathrm{CH}_{3} \mathrm{OH}\left(\mathrm{Ti}_{5 \mathrm{c}}\right)+h v & \rightarrow \mathrm{CH}_{3} \mathrm{O}\left(\mathrm{Ti}_{5 \mathrm{c}}\right)+\mathrm{H}_{\mathrm{BBO}} \\
\mathrm{CH}_{3} \mathrm{O}\left(\mathrm{Ti}_{5 \mathrm{c}}\right)+h v & \rightarrow \mathrm{CH}_{2} \mathrm{O}\left(\mathrm{Ti}_{5 \mathrm{c}} \mathrm{c}\right)+\mathrm{H}_{\mathrm{BBO}}
\end{aligned}
$$

The above results indicate that $\mathrm{CH}_{3} \mathrm{OH}$ photocatalysis in the presence of $\mathrm{H}_{2} \mathrm{O}$ is very similar to that of $\mathrm{CH}_{3} \mathrm{OH}$ photocatalytic dissociation on the same surface without $\mathrm{H}_{2} \mathrm{O}$. It is interesting to point out that methoxy $\left(\mathrm{CH}_{3} \mathrm{O}\right)$ is a key intermediate in
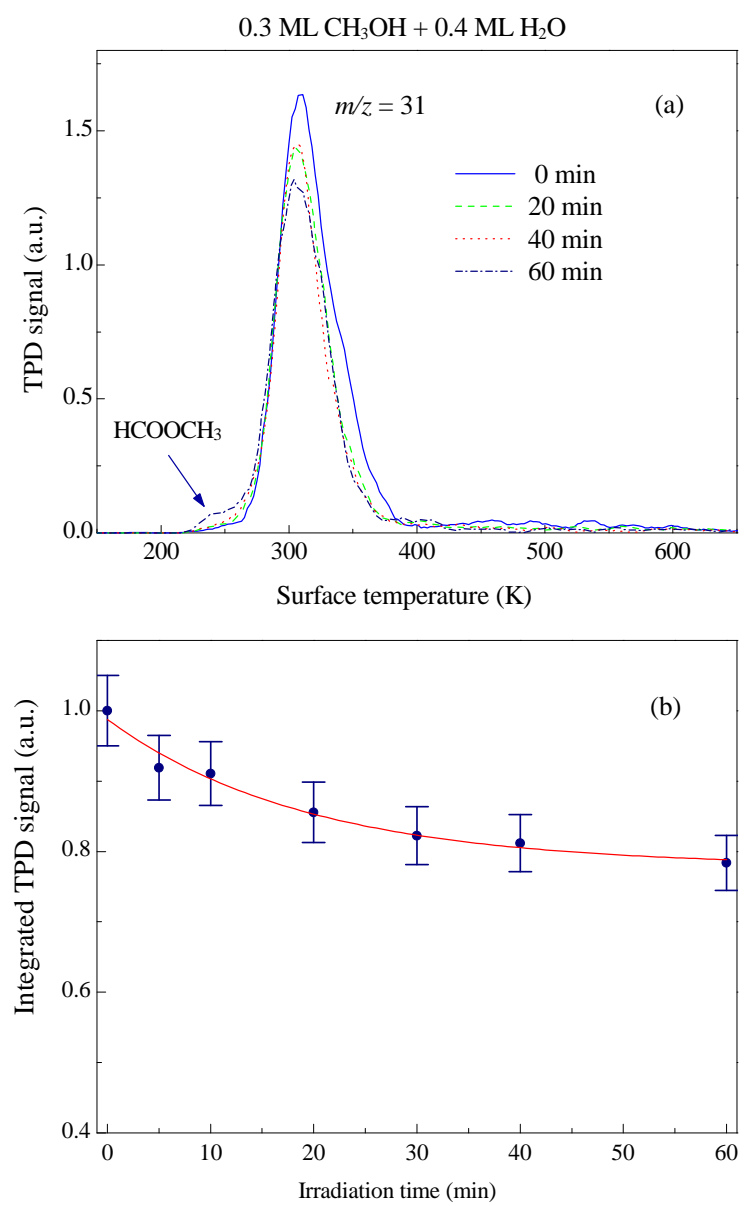

Fig. 3. (a) TPD spectra taken at $m / z=31$ at four different laser irradiation times for the $0.3 \mathrm{ML} \mathrm{CH}_{3} \mathrm{OH}+0.4 \mathrm{ML} \mathrm{H}_{2} \mathrm{O}$ covered rutile $\mathrm{TiO}_{2}(110)$ $-(1 \times 1)$ surface; (b) The integrated signal of the TPD peak at $315 \mathrm{~K}$ at mass 31 shown in (a) after the surface was irradiated with $400 \mathrm{~nm}$ laser light for different periods of time.

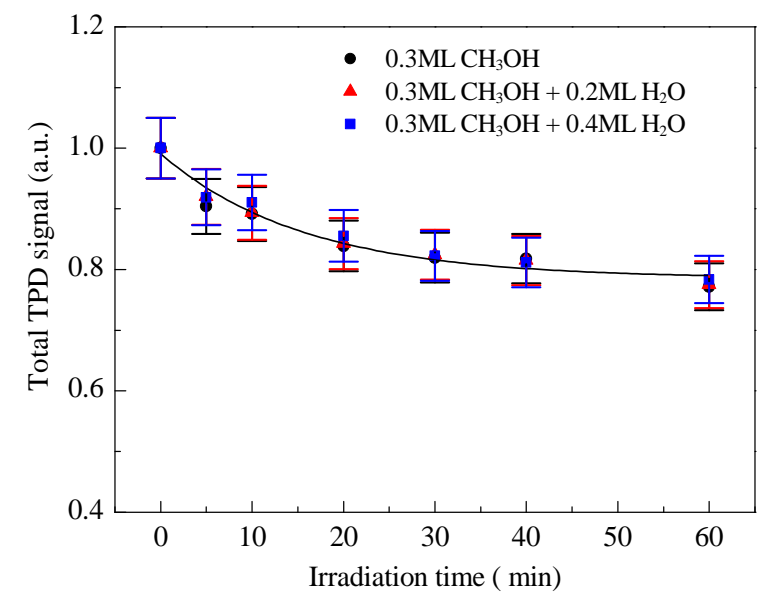

Fig. 4. The integrated signal of the TPD peak at $315 \mathrm{~K}$ at $m / z=31$ shown in Figs. 1, 2, and 3 after the three different surfaces (0.3 ML $\mathrm{CH}_{3} \mathrm{OH} /$ rutile $\mathrm{TiO}_{2}(110)-(1 \times 1), 0.3 \mathrm{ML} \mathrm{CH}_{3} \mathrm{OH}+0.2 \mathrm{ML} \mathrm{H}_{2} \mathrm{O} /$ rutile $\mathrm{TiO}_{2}(110)-(1 \times 1), 0.3 \mathrm{ML} \mathrm{CH}_{3} \mathrm{OH}+0.4 \mathrm{ML} \mathrm{H}_{2} \mathrm{O} /$ rutile $\mathrm{TiO}_{2}(110)-(1 \times$ 1)) were irradiated with $400 \mathrm{~nm}$ laser light for different periods of time. The integrated signals shown were all normalized at time zero.

$\mathrm{CH}_{3} \mathrm{OH}$ photocatalytic dissociation. The presence of $\mathrm{CH}_{3} \mathrm{O}$ is also indirectly confirmed by photocatalytic synthesis of methyl 


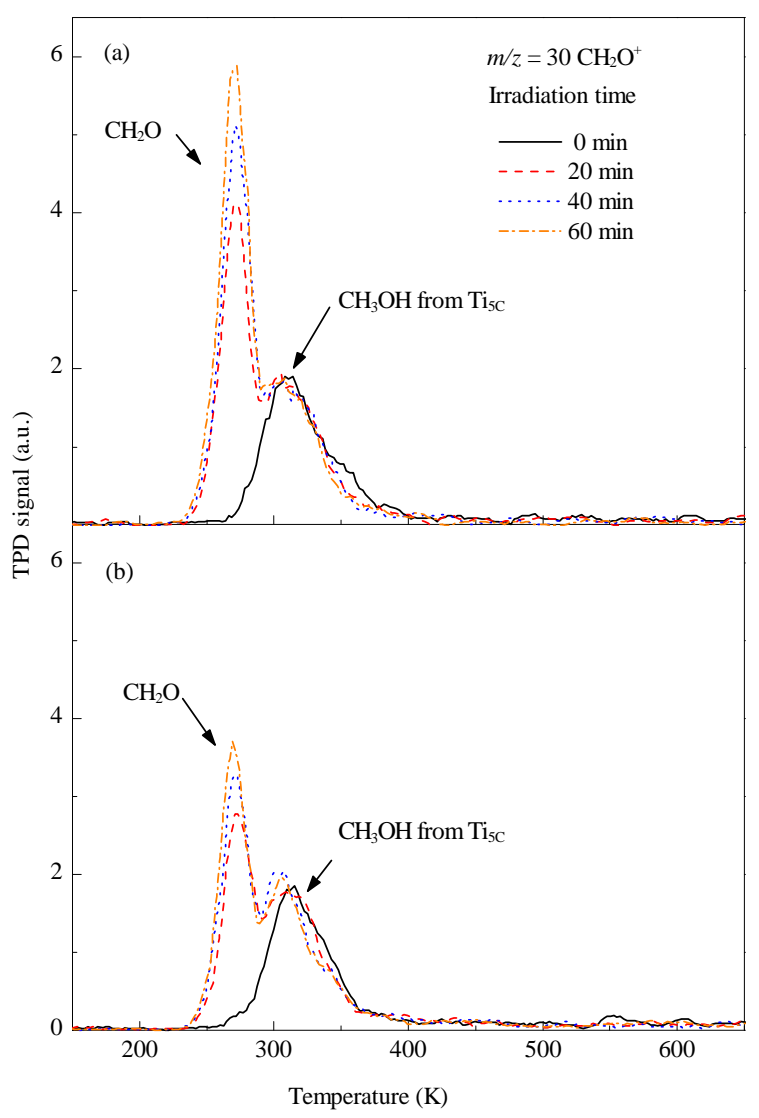

Fig. 5. (a) TPD spectra taken at $m / z=30$ at four different laser irradiation times for $0.3 \mathrm{ML} \mathrm{CH}_{3} \mathrm{OH}+0.2 \mathrm{ML} \mathrm{H}_{2} \mathrm{O}$ covered rutile $\mathrm{TiO}_{2}(110)-(1 \times$ 1) surface; (b) TPD spectra taken at $m / z=30$ at four different laser irradiation times for $0.3 \mathrm{ML} \mathrm{CH}_{3} \mathrm{OH}$ only covered $\mathrm{TiO}_{2}(110)$ surface.

formate $\left(\mathrm{HCOOCH}_{3}\right)$ via cross coupling of $\mathrm{CH}_{2} \mathrm{O}$ and $\mathrm{CH}_{3} \mathrm{O}$ on rutile $\mathrm{TiO}_{2}(110)-(1 \times 1)[28,29]$.

For the $\mathrm{CH}_{2} \mathrm{O}$ product formation process, we compared the $\mathrm{CH}_{3} \mathrm{OH}$ covered rutile $\mathrm{TiO}_{2}(110)-(1 \times 1)$ surface with the $0.3 \mathrm{ML}$ $\mathrm{CH}_{3} \mathrm{OH}+0.2 \mathrm{ML} \mathrm{H}_{2} \mathrm{O}$ covered rutile $\mathrm{TiO}_{2}(110)-(1 \times 1)$ surface. Figure 5(b) shows several TPD spectra at $m / z=30\left(\mathrm{H}_{2} \mathrm{CO}^{+}\right)$for $0.3 \mathrm{ML}$ of $\mathrm{CH}_{3} \mathrm{OH}$ covered surface in comparison with that obtained for a $0.3 \mathrm{ML} \mathrm{CH}_{3} \mathrm{OH}+0.2 \mathrm{ML} \mathrm{H}_{2} \mathrm{O}$ coadsorbed surface. The results are very intriguing. It appears that the signal level of $\mathrm{CH}_{2} \mathrm{O}$ TPD product for $\mathrm{CH}_{3} \mathrm{OH}$ and $\mathrm{H}_{2} \mathrm{O}$ coadsorbed surface is noticeably smaller (about 1.5 times smaller) than that for the surface only covered with $\mathrm{CH}_{3} \mathrm{OH}$. To trace the origin of this phenomenon, we also carried out time of flight (TOF) measurements for photodesorbed products at $m / z=30$ (Fig. 6) and found that photo-induced desorption of the $\mathrm{CH}_{2} \mathrm{O}$ product by $400 \mathrm{~nm}$ light was also noticeably smaller for the $\mathrm{CH}_{3} \mathrm{OH}$ only adsorbed surface. The integrated TOF signal between 0 to $150 \mathrm{~s}$ is incidentally about 1.5 times smaller for the $\mathrm{CH}_{3} \mathrm{OH}$ only adsorbed surface. These results seem to indicate that photo-induced desorption of $\mathrm{CH}_{2} \mathrm{O}$ products was suppressed by the presence of water. This implies that water acted as an efficient energy absorber so that less energy was available for formaldehyde product photo-desorption. These results also suggest that water actually affects the gaseous formaldehyde formation process in methanol photocatalysis on rutile $\mathrm{TiO}_{2}(110)-(1 \times 1)$

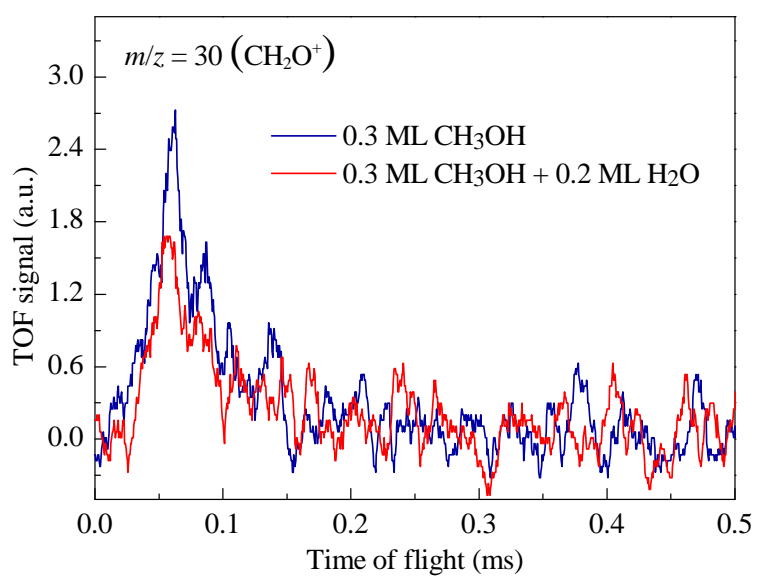

Fig. 6. Time of flight (TOF) data for photodesorbed products at $m / z=$ $30\left(\mathrm{CH}_{2} \mathrm{O}^{+}\right)$during laser irradiation for $0.3 \mathrm{ML} \mathrm{CH}_{3} \mathrm{OH}$ covered $\mathrm{TiO}_{2}(110)$ surface and the $0.3 \mathrm{ML} \mathrm{CH} \mathrm{CH}_{3} \mathrm{OH}+0.2 \mathrm{ML} \mathrm{H}_{2} \mathrm{O}$ covered rutile $\mathrm{TiO}_{2}(110)-(1 \times 1)$ surface.
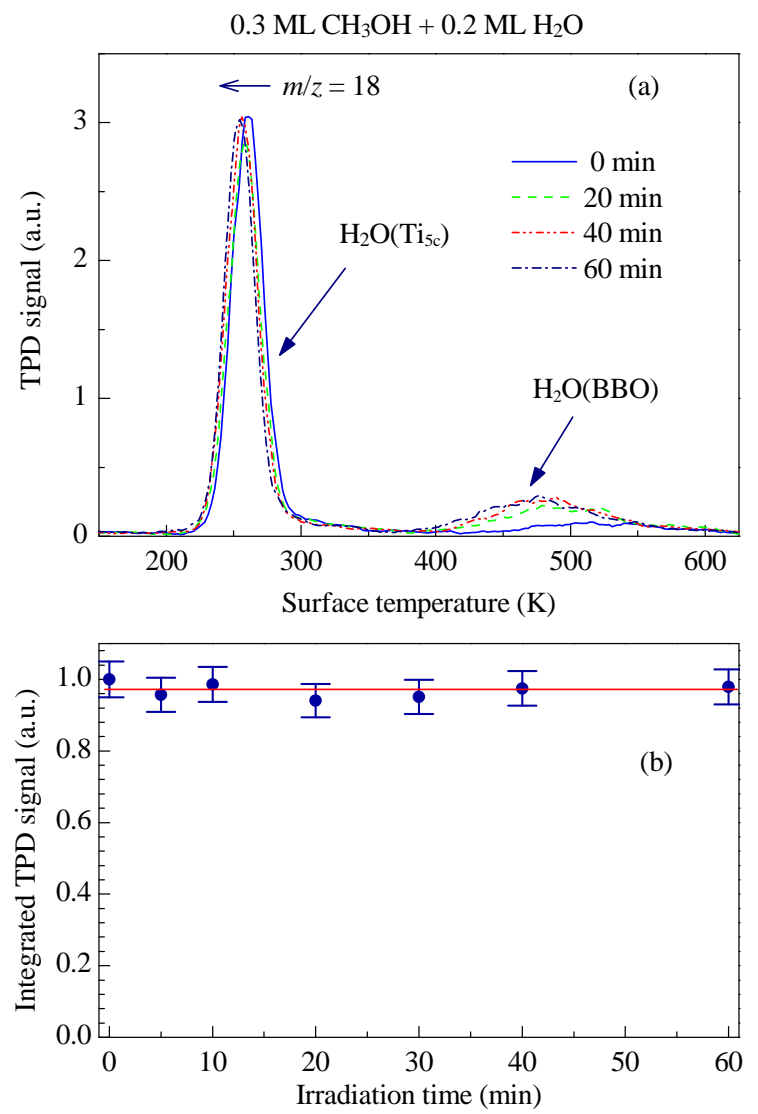

Fig. 7. (a) TPD spectra taken at $m / z=18$ at four different laser irradiation times; (b) Integrated signal of the TPD peak at $260 \mathrm{~K}$ at $m / z=18$ after the $\mathrm{CH}_{3} \mathrm{OH} / \mathrm{H}_{2} \mathrm{O}$ covered rutile $\mathrm{TiO}_{2}(110)-(1 \times 1)$ surface was irradiated with $400 \mathrm{~nm}$ laser light for different periods of time.

even though it does not seem to affect the photocatalytic dissociation step.

To determine whether $\mathrm{CH}_{3} \mathrm{OH}$ or $\mathrm{CH}_{3} \mathrm{O}$ have any enhancing effect on water splitting on rutile $\mathrm{TiO}_{2}(110)-(1 \times 1)$, we also measured the TPD signal at mass $18\left(\mathrm{H}_{2} \mathrm{O}^{+}\right)$for the rutile $\mathrm{TiO}_{2}(110)-(1 \times 1)$ surface covered with $0.3 \mathrm{ML}$ of $\mathrm{CH}_{3} \mathrm{OH}$ and $0.2 \mathrm{ML}$ of $\mathrm{H}_{2} \mathrm{O}$ at different laser irradiation times. Figure 7(a) 
shows a few typical TPD spectra at mass $18\left(\mathrm{H}_{2} \mathrm{O}^{+}\right)$with laser irradiation times of 0 to $60 \mathrm{~min}$. The main feature around $260 \mathrm{~K}$ in the spectra is due to the desorption of molecular $\mathrm{H}_{2} \mathrm{O}$ from Tisc sites. From the TPD spectra, it is clear that $400 \mathrm{~nm}$ laser irradiation shifts this feature slightly towards lower temperature. This shift is caused by the increasing density of $\mathrm{H}$ atoms on the BBO sites because of $\mathrm{CH}_{3} \mathrm{OH}$ dissociation. The peak height of the main feature, however, did not change much with laser irradiation time. We integrated this main peak in the TPD at different irradiation times, as shown in Fig. 7(b). In the presence of $\mathrm{CH}_{3} \mathrm{OH}$, the main $\mathrm{H}_{2} \mathrm{O}$ TPD peak intensity at $m / z=$ 18 did not change within the experimental uncertainty. We also measured the $\mathrm{H}_{2} \mathrm{O}$ TPD spectra and total TPD signal of the main peak at $260 \mathrm{~K}$ as a function of laser irradiation time for the 0.3 $\mathrm{ML} \mathrm{CH}_{3} \mathrm{OH}+0.4 \mathrm{ML} \mathrm{H}_{2} \mathrm{O}$ covered rutile $\mathrm{TiO}_{2}(110)-(1 \times 1)$ surface (Fig. 8). The obtained result is nearly identical to that of the $0.3 \mathrm{ML} \mathrm{CH}_{3} \mathrm{OH}+0.2 \mathrm{ML} \mathrm{H}_{2} \mathrm{O}$ covered surface. These experimental results clearly show that $\mathrm{CH}_{3} \mathrm{OH}$ cannot enhance water splitting at $400 \mathrm{~nm}$ on rutile $\mathrm{TiO}_{2}(110)-(1 \times 1)$ in a noticeable way. In addition, because $\mathrm{CH}_{3} \mathrm{O}$ is also present as a key intermediate in the photocatalytic dissociation of $\mathrm{CH}_{3} \mathrm{OH}$, our results imply that $\mathrm{CH}_{3} \mathrm{O}$ has no effect in enhancing photocatalytic $\mathrm{H}_{2} \mathrm{O}$ dissociation on $\mathrm{TiO}_{2}$.

Previous studies demonstrate that photocatalytic synthesis
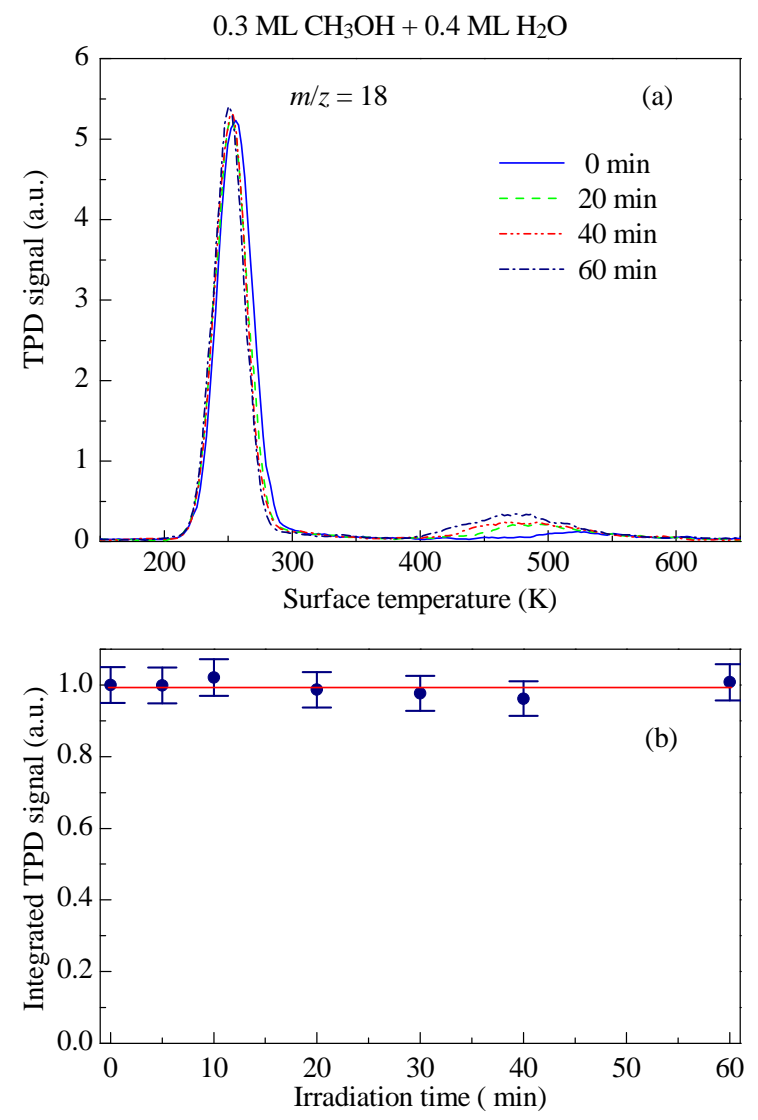

Fig. 8. (a) TPD spectra taken at $m / z=18$ at four different laser irradiation times for the $0.3 \mathrm{ML} \mathrm{CH}_{3} \mathrm{OH}+0.4 \mathrm{ML} \mathrm{H}_{2} \mathrm{O}$ covered rutile $\mathrm{TiO}_{2}(110)$ $-(1 \times 1)$ surface; (b) Integrated signal of the TPD peak at $260 \mathrm{~K}$ at $m / z=$ 18 shown in the upper panel after the surface was irradiated with 400 nm laser light for different periods of time. of $\mathrm{HCOOCH}_{3}$ via cross coupling of $\mathrm{CH}_{2} \mathrm{O}$ and $\mathrm{CH}_{3} \mathrm{O}$ happens on $0.5 \mathrm{ML}$ of $\mathrm{CH}_{3} \mathrm{OH}$ covered $\mathrm{TiO}_{2}$ (110) [28,29]. In this work, no $\mathrm{HCOOCH}_{3}$ was formed with only $0.3 \mathrm{ML}$ of $\mathrm{CH}_{3} \mathrm{OH}$ covered rutile $\mathrm{TiO}_{2}(110)-(1 \times 1)$ due to low $\mathrm{CH}_{3} \mathrm{OH}$ coverage. However, with increasing coverage of coadsorbed $\mathrm{H}_{2} \mathrm{O}$, a little shoulder became obvious at the low temperature edge of the $315 \mathrm{~K}$ peak in the mass 31 TPD trace. Although the shoulder is very small, its presence implies that $\mathrm{H}_{2} \mathrm{O}$ can enhance the efficiency of photocatalytic synthesis of $\mathrm{HCOOCH}_{3}$ by occupying $\mathrm{Ti}_{5 \mathrm{c}}$ sites on the surface and thereby increase the opportunity that $\mathrm{CH}_{2} \mathrm{O}$ and $\mathrm{CH}_{3} \mathrm{O}$ are adjacent to each other, similar to recent observations on noble metal modified $\mathrm{TiO}_{2}$ photocatalysts [30].

For $\mathrm{TiO}_{2}$, separated holes and electrons generated by photons are believed to be the driving force for reaction, desorption, and so on [7]. Our results show that the desorption temperature of $\mathrm{H}_{2} \mathrm{O}$ and product $\mathrm{CH}_{2} \mathrm{O}$ are 260 and $270 \mathrm{~K}$ for $\mathrm{CH}_{3} \mathrm{OH}$ and $\mathrm{H}_{2} \mathrm{O}$ coadsorbed rutile $\mathrm{TiO}_{2}(110)-(1 \times 1)$, respectively. TOF measurements only observe photo-induced desorption of the $\mathrm{CH}_{2} \mathrm{O}$ product, which can be inhibited by the presence of $\mathrm{H}_{2} \mathrm{O}$. These phenomena indicate that photo-induced desorption of the $\mathrm{CH}_{2} \mathrm{O}$ product is not only a simple hole or electron driven process. Previous studies [31,32] demonstrate that $\mathrm{H}_{2} \mathrm{O}$ molecules can form hydrogen bonds with bridging oxygen sites or $\mathrm{H}_{2} \mathrm{O}$ molecules on rutile $\mathrm{TiO}_{2}(110)-(1 \times 1)$. Here, no observation of TOF signal of $\mathrm{H}_{2} \mathrm{O}$ suggests that the excitiation energy for $\mathrm{H}_{2} \mathrm{O}$ desorption may be relaxed by complicated hydrogen bonds or hydrogen bond network, as well as deceased TOF signal of $\mathrm{CH}_{2} \mathrm{O}$ when $\mathrm{H}_{2} \mathrm{O}$ is present on rutile $\mathrm{TiO}_{2}(110)-(1 \times 1)$. Thus, a few issues need to be closely examined. Primarily, there is clearly a need to clarify the exact picture of how separated holes and electrons, or even phonons created by hole and electron recombination, interact with reactants and the energy transfer channel for reaction, desorption, and so on.

\section{Conclusions}

Photocatalytic dissociation of $\mathrm{CH}_{3} \mathrm{OH}$ on rutile $\mathrm{TiO}_{2}(110)-(1$ $\times 1$ ) occurs through $\mathrm{O}-\mathrm{H}$ bond and $\mathrm{C}-\mathrm{H}$ bond cleavage in adsorbed $\mathrm{CH}_{3} \mathrm{OH}$, yielding $\mathrm{CH}_{2} \mathrm{O}$ and two surface $\mathrm{OH}$ groups. Coadsorbed $\mathrm{H}_{2} \mathrm{O}$ does not promote photochemistry for molecularly adsorbed $\mathrm{CH}_{3} \mathrm{OH}$, and coadsorbed $\mathrm{CH}_{3} \mathrm{OH}$ does not affect $\mathrm{H}_{2} \mathrm{O}$ photoactivity. However, coadsorbed $\mathrm{H}_{2} \mathrm{O}$ can enhance formation of the $\mathrm{HCOOCH}_{3}$ product. $\mathrm{H}_{2} \mathrm{O}$ molecules hydrogen-bonded to bridging oxygen sites or $\mathrm{CH}_{2} \mathrm{O}$ may be the cause of the inhibited photo-induced desorption of $\mathrm{CH}_{2} \mathrm{O}$, suggesting that hydrogen bonds may play an important role in energy transfer. Further work is needed to focus on the role of hydrogen bonds.

\section{References}

[1] Fujishima A, Honda K. Nature, 1972, 238: 37

[2] Fox M A, Dulay M T. Chem Rev, 1993, 93: 341

[3] Linsebigler A L, Lu G, Yates J T Jr. Chem Rev, 1995, 95: 735

[4] Khan S U M, Al-Shahry M, Ingler W B Jr. Science, 2002, 297: 2243

[5] Mi Q, Chen D Q, Hu J C, Huang Z X, Li J L. Chin J Catal (米倩, 陈带 


\title{
Graphical Abstract
}

Chin. J. Catal., 2013, 34: 416-422 doi: 10.1016/S1872-2067(14)60006-1

\section{The role of water in photocatalytic dissociation of methanol on rutile $\mathrm{TiO}_{2}(110)-(1 \times 1)$}

Chenbiao Xu, Wenshao Yang, Qing Guo*, Dongxu Dai, Maodu Chen, Xueming Yang*

Dalian University of Technology; Dalian Institute of Chemical Physics, Chinese Academy of Sciences
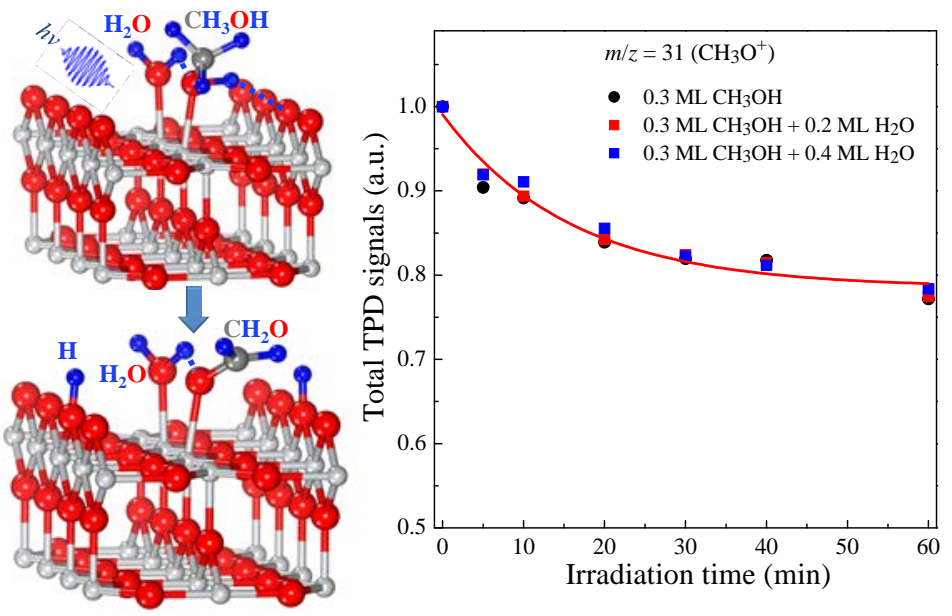

Coadsorbed water on methanol covered $\mathrm{TiO}_{2}(110)-(1 \times 1)$ surface has nearly no effect on methanol photodissociation.

全, 胡军成, 黄正喜, 李金林. 催化学报), 2013, 34: 2138

[6] Kamat P V. Chem Rev, 1993, 93: 267

[7] Henderson M A. Surf Sci Rep, 2011, 66: 185

[8] Hoffmann M R, Martin S T, Choi W, Bahnemann D W. Chem Rev, 1995, 95: 69

[9] Chen X F, Zhang J, Huo Y N, Li H X. Chin J Catal (陈晓芳, 张佳, 霍 宇凝，李和兴. 催化学报), 2013, 34: 949

[10] Sato S, White J M. Chem Phys Lett, 1980, 72: 83

[11] Kawai T, Sakata T. J Chem Soc, Chem Commun, 1980: 694

[12] Bates S P, Gillan M J, Kresse G.J Phys Chem B, 1998, 102: 2017

[13] Henderson M A, Otero-Tapia S, Castro M E. Faraday Discuss, 1999, 114: 313

[14] Pang C L, Lindsay R, Thornton G. Chem Soc Rev, 2008, 37: 2328

[15] Farfan-Arribas E, Madix R J. Surf Sci, 2003, 544: 241

[16] De Armas R S, Oviedo J, San Miguel M A, Sanz J F. J Phys Chem C, 2007, 111: 10023

[17] Oviedo J, De Armas R S, San Miguel M A, Sanz J F. J Phys Chem C, 2008, 112: 17737

[18] Sánchez V M, Cojulun J A, Scherlis D A. J Phys Chem C, 2010, 114: 11522

[19] Zhao J, Yang J L, Petek H. Phys Rev B, 2009, 80: 235416

[20] Wong G S, Kragten D D, Vohs J M.J Phys Chem B, 2001, 105: 1366
[21] Shen M, Henderson M A.J Phys Chem Lett, 2011, 2: 2707

[22] Ahmed A Y, Kandiel T A, Oekermann T, Bahnemann D. J Phys Chem Lett, 2011, 2: 2461

[23] Zhang Z, Bondarchuk O, White J M, Kay B D, Dohnalek Z. J Am Chem Soc, 2006, 128: 4198

[24] Onda K, Li B, Zhao J, Petek H. Surf Sc, 2005, 593: 32

[25] Li B, Zhao J, Onda K, Jordan K D, Yang J, Petek H. Science, 2006, 311: 1436

[26] Zhou C Y, Ren Z F, Tan S J, Ma Z B, Mao X C, Dai D X, Fan H J, Yang X M, LaRue J, Cooper R, Wodtke A M, Wang Z, Li Z Y, Wang B, Yang J L, Hou J G. Chem Sci, 2010, 1: 575

[27] Guo Q, Xu C B, Ren Z F, Yang W S, Ma Z B, Dai D X, Fan H J, Minton T K, Yang X M. J Am Chem Soc, 2012, 134: 13366

[28] Yuan Q, Wu Z E, Jin Y K, Xu L S, Xiong F, Ma Y S, Huang W X. J Am Chem Soc, 2013, 135: 5212

[29] Guo Q, Xu C B, Yang W S, Ren Z F, Ma Z B, Dai D X, Minton T K, Yang X M. J Phys Chem C, 2013, 117: 5293

[30] Chiarello G L, Aguitte M H, Selli E. J Catal, 2010, 273: 182

[31] Kimmel G A, Baer M, Petrik N G, VandeVondele J, Rousseau R, Mundy C J.J Phys Chem Lett, 2012, 3: 778

[32] Lee J, Sorescu D C, Deng X, Jordan K D. J Phys Chem Lett, 2013, 4: 53

\section{水对甲醇在Rutile- $\mathrm{TiO}_{2}(110)-(1 \times 1)$ 表面光催化解离的影响}

\author{
徐晨彪 ${ }^{\mathrm{a}, \mathrm{b}}$, 杨文绍 ${ }^{\mathrm{b}}$, 郭 庆 ${ }^{\mathrm{b}, *}$, 戴东旭 ${ }^{\mathrm{b}}$, 陈茂笃 ${ }^{\mathrm{a}}$, 杨学明 ${ }^{\mathrm{b}, \#}$ \\ a大连理工大学物理与光电工程学院, 辽宁大连 116023 \\ b 中国科学院大连化学物理研究所分子反应动力学国家重点实验室, 辽宁大连116023
}


分子以及甲醇分子与水分子共吸附情况下的光催化解离过程. 结果表明, 在二氧化钢(110)表面吸附的甲醇分子对共吸附水分子 的光催化解离过程并没有直接的帮助作用. 共吸附状态下的水分子也同样没有影响到甲醇的光致解离过程, 但是水分子的存在 抑制了甲醇光解产物甲醛的光致脱附过程, 同时促进了甲酸甲酯的形成.

关键词: 甲醇; 水; 金红石二氧化钛(110)-(1 × 1)表面; 光催化; 程序升温脱附; 甲醛

收稿日期: 2013-11-23. 接受日期: 2013-12-13. 出版日期: 2014-03-20.

*通讯联系人. 电话: (0411)84379337; 传真: (0411)84675584; 电子信箱: guoqing@dicp.ac.cn

\#通讯联系人. 电话: (0411)84695174; 传真: (0411)84675584; 电子信箱: xmyang@dicp.ac.cn 基金来源：国家重点基础研究发展计划(973计划, 2013CB834605); 国家自然科学基金(20923002).

本文的英文电子版由Elsevier出版社在ScienceDirect上出版(http://www.sciencedirect.com/science/journal/18722067). 